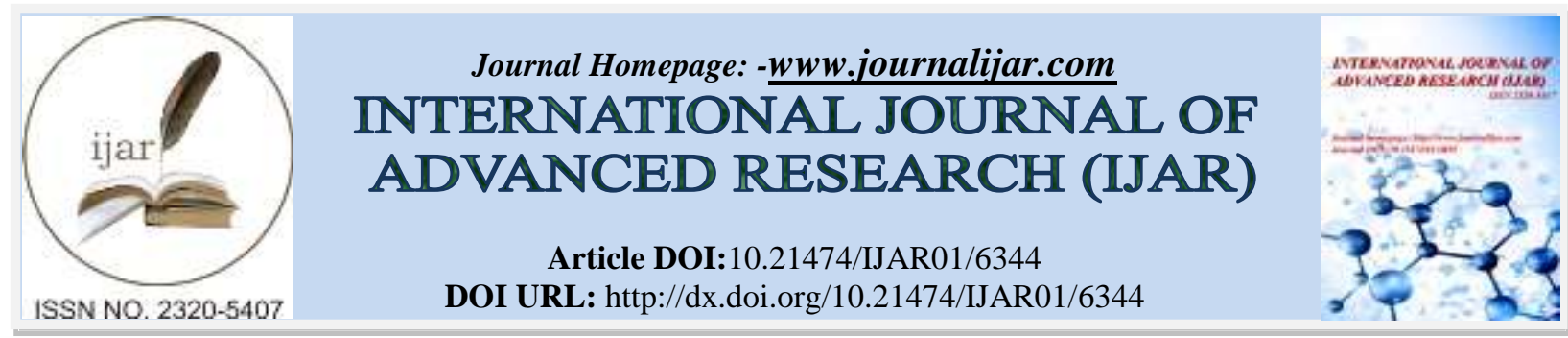

RESEARCH ARTICLE

\title{
THE IMPLEMENTATION OF CONSTITUTIONAL COURT DECISION IN THE JUDICIAL REVIEW OF LAW NUMBER 22 YEAR 2001 CONCERNING OIL AND GAS FOLLOWED BY PRESIDENTIAL REGULATION.
}

1. Graduate School, Faculty of Law, Hasanuddin University.

2. Faculty of Law, Hasanuddin University.

\section{Manuscript Info}

\section{(..............................}

Manuscript History

Received: 18 November 2017

Final Accepted: 20 December 2017

Published: January 2018

\section{Key words:-}

Legal Implications, Legal Force, Oil and Gas, Presidential Regulation, Decision of the Constitutional Court.

\begin{abstract}
Based on Law Number 24 of 2003 as amended by Law Number 8 of 2011 in the Constitutional Court, that the Final Power and Binding Decisions of the Constitutional Court have obtained a permanent legal force since the decision is made and no legal cure can be taken, applies only to the parties but applies to all citizens, Executorial powers The Constitutional Court rule is deemed to have materialized in the form of an announcement contained in state news within a maximum period of 30 days from the date of the verdict being pronounced in a plenary session open to the public. The legal implications that occur in the presidential regulation as a follow-up of the decision of the constitutional court in the examination of Law Number 22 of 2001 on oil and gas stated that some of the articles are on the contrary to the 1945 Constitution of the State of the Republic of Indonesia and have no legal force binding and immediately issuing a new law but in reality, the decision of the constitutional court followed up with presidential regulations.
\end{abstract}

Copy Right, IJAR, 2018,. All rights reserved.

\section{Introduction:-}

The Constitution of the Republic of Indonesia of the third amendment result has affirmed that the state of Indonesia is a state law. This norm is meaningful in the Republic of Indonesia, law is the lifeblood of all aspects of life. ${ }^{1}$ Therefore, the order of life of the people, nation and state must be guided by legal norms. ${ }^{2}$ The law should be placed as the highest reference in the whole process of state administration. ${ }^{3}$

In such a context, the state places the law as the basis of state power and the exercise of that power in all its forms is exercised under the rule of law. Logical consequence, the entire system of state administration must be based on the

\footnotetext{
${ }^{1}$ MarwanEffendy. 2005. Kejaksaan RI: Posisi dan Fungsinya Dari PerspektifHukum. GramediaPustakaUtama. Jakarta. Hlm.1

${ }^{2}$ BambangSutijoyo dan Sri HastutiPuspitasari. 2005. Aspek-AspekPerkembanganKekuasaanKehakimanIndonesia. UII Press. Yogyakarta. Hlm.9.

${ }^{3}$ JimlyAsshiddiqie. 2010. Konstitusi dan KonstitusionalismeIndonesia. SinarGrafika. Jakarta. Hlm. 57.
} 
constitution. ${ }^{4}$ The administration of the state delegated to the state organs must proceed in accordance with the legal corridors prescribed by the constitution. ${ }^{5}$ Shortly, every administration of state or government power is always awakened by and grounded in the principles and provisions of the constitution.

Post amendment of the Constitution of the Republic of Indonesia for four times (1999-2002), the constitution of Indonesia has changed principally. Started from the regulation of the principle of people's sovereignty, the application of Trias Politica consequently to the system of separation of powers and checks and balances in the implementation of state administration. It is marked the sovereignty of the state has fully been on the people, previously mandated to the People's Consultative Assembly. The shifting power of legislators from the President (executive), to the House of Representatives (legislative). Meanwhile, changes to the previous judicial powers are fully exercised by the Supreme Court. However, currently some judicial powers are implemented by a new institution namely the Constitutional Court as the guardian of constitution.

The main purpose of the establishment of the Constitutional Court in Indonesia is to ensure that there are no laws which contra to the Constitution of the Republic of Indonesia. Any law made in order to provide legal arrangements for the public shall not be contradictionary to the constitution as the supreme law of the State. ${ }^{6}$ That is why, the Constitutional Court is said to be the guardian of the constitution and the sole and binding interpreter of the constitution. $^{7}$

The authority of the Constitutional Court under article 24C paragraph 1 of the Constitution of the Republic of Indonesia and Article 10 paragraph 1 sub-paragraph a of Law Number 24 of 2003 as amended by Law Number 8 of 2011 on the Constitutional Court authorized to test the law against the Constitution. With that authority, the Constitutional Court may examine and even invalidate a law if it is believed to be contrary to the Constitution. If contradictory, the Constitutional Court Judge gives a final and binding decision stating that some of the material or the whole of the law can be declared no longer in force of binding to the public. Consequently, all parties must obey with changes in the legal circumstances created through the decision of the Constitutional Court and implement it.

Although the authority of the Constitutional Court is to examine and cancel the law if it is believed to be contrary to the constitution. However, facts show that final and binding decisions are often not responded positively by other state agencies. ${ }^{8}$ This shows that any decision of the Constitutional Court even if final and binding will always be problematic at the time of implementation of its decision. ${ }^{9}$ The Constitutional Court ruling often shows a distinction between the stage of reading and implementation of the final decision so that the final decision, the Constitutional Court Decision will only have a symbolic power that is limited to decorate the news sheets of the country.

This fact can be clearly seen in the Decision of the Constitutional Court related to the Tests of the Law against the Constitution of the Republic of Indonesia. For example, the Constitutional Court Decision Number 002/PUU-I/2003 granting the Petitioners' Petition for part of Article 12 Paragraph (3), Article 22 (1) and Article 28 Paragraph (2) and Paragraph (3) of Law Number 22 Year 2001 on Oil and Gas as opposed to Article 33 of the Constitution of the Republic of Indonesia. This final and binding verdict should be followed up. However, the government actually issued Presidential Regulation Number 55 of 2005 on Retail Price of Domestic Fuel Oil, which precisely arranged against the decision of the Constitutional Court. The problem is, the government actually sets the price of Fuel Oil on the market mechanism. In fact, the Constitutional Court has declared several articles and paragraphs behind Law Number 22 Year 2001 on Oil and Gas is contrary to the Constitution of the Republic of Indonesia.

The same is again repeated in relation to the judicial review of Law Number 22 Year 2001 regarding Oil and Gas on the Decision of the Constitutional Court Number 36/PUU-X/2012, where the Constitutional Court in its ruling states that the Oil and Gas Executing Agency is opposing to the Constitution of the Republic of Indonesia and has no binding legal force and submits the functions and duties of the Executing Agency of Oil and gas implemented by the

${ }^{4}$ Moh. Mahfud MD. 2007. PerdebatanHukum Tata negaraPascaAmandemenKonstitusi. LP3ES. Jakarta. Hlm.57.

5 Jimly Asshiddiqie, Op.cit., Hlm.17.

${ }^{6}$ Maria Farida Indrati S. 2007. Ilmu Perundang-Undangan 1. Penerbit Kanisius. Jakarta. Hlm. 46-47.

${ }_{8}^{7}$ Mahfud MD. Op.cit., Hlm. 97.

${ }^{8}$ Ahmad Syahrizal. 2007. "Problem Implementasi Putusan Mahkamah Konstitusi" Jurnal Konstitusi, Volume 1, Nomor 4, Maret 2007. Hlm. 107.

${ }^{9}$ Ibid., 
relevant ministries up to the formation of a new law. As a follow up, after the issuance of the Decree of the President of the Republic of Indonesia Number 09 Year 2013 regarding the Management of Upstream Oil and Gas Business Activities.

Oil and gas business activities are always required to support the sustainability of national development in order to increase the prosperity and wealth of the people above. To make this happen, enacted Law Number 22 Year 2001 on Oil and Gas. This Law is the legal base for the steps to renew and restore business activities in the oil and gas sector. Based on Law Number 22 Year 2001 regarding Oil and Gas, in the oil and gas business activities there are upstream and downstream businesses. Upstream business consists of exploration and exploitation activities. Meanwhile, downstream business consists of processing, transportation, storage and trading activities. Upstream business activities are carried out under a cooperation contract with the implementing agency. To the downstream business is carried out after obtaining permission from the Ministry of Energy and Mineral Resources. Ministry of Energy and mineral resources through the Oil and Gas Executing Agency which is subsequently replaced by the name of Special Unit for Upstream Oil and Gas Business Activities of "single" authority holders in upstream oil and gas business. ${ }^{10}$ However, following the Constitutional Court's decision, the President issued a Presidential Regulation by establishing a Special Unit for Upstream Oil and Gas Activities. The existence of Special Units of Oil and Gas following the dissolution of the Executing Agency of oil and gas. is not considered to comply with the Decision of the Constitutional Court Number 36/PUU-X/2012. This can be seen from the duty of the Special Unit for Oil and Gas contained in Article 3 of Regulation of the Minister of Energy and Mineral Resources Number 9 of 2013 on the Organization and Working Procedures of the Special Unit for Upstream Oil and Gas Business Activities, then the Regulation of the Minister of Energy and Mineral Resources Number 9 of 2013 is revoked and replaced by Regulation of Minister of Energy and Mineral Resources Number 17 Year 2017 on Organization and Working Procedure of Special Unit for Upstream Oil and Gas Business Activities in which One Work Special Oil and gas regulated in Articles 3 and 4 of the duties and functions of the Special Unit for Oil and Gas are the same as the Previous Regulations. Based on the background of the problem, it can be formulated as follows: How the Legal Power of Constitutional Court Ruling In the Examination of Law Number 22 Year 2001 on Oil and Gas and How the Law Implications the Presidential Regulation as a follow-up of the Constitutional Court Decision in the Tests of Law Number 22 Year 2001 on Oil and Gas?

\section{Method of the Research:-}

This research is legal juridical normative research. Normative legal research or also called literature research is "Legal research conducted by examining the library materials or secondary data only". ${ }^{11}$ The source of secondary legal material used in this writing is a Scientific Work in the form of a thesis or dissertation, especially in terms of views or forms of analysis of the Constitutional Court Decision followed up by Presidential Regulation. Books, Literatures, legal journals and writings in particular relating to Decisions of the Constitutional Court which are followed up by Presidential Regulation.

\section{Results and Discussion:-}

The Law Power of The Constitutional Court's Decision In The Tests of Law Number 22 Year 2001 Concerning Oil and Gas:-

Final Strength and Binding Decisions of the Constitutional Court:-

The final nature of the Constitutional Court's decision refers to the desire to immediately realize legal certainty for justice seekers. Therefore, since the judgment of the Constitutional Court's judgment, the decision has been enforced (in kracht) so that there is no longer any access for the parties to pursue other legal measurements. That is, since the verdict coming out, it is valid and immediately to be executed. The nature of the decision of the Constitutional Court is nothing but it is an attempt to maintain the authority of constitutional court. Because, if the constitutional court accommodates the existence of legal restructuration, it is no different from the general court. In general courts usually cases that have been decided will be re-submitted advanced legal efforts, it will take a long time until the

\footnotetext{
${ }^{10}$ Ivan Fauzani Raharja. 2016. Penerapan Sanksi Administrasi Terhadap Perusahaan Yang Melanggar Ketentuan Perizinan Minyak dan Gas Bumi. Jurnal Ilmu Hukum, Volume 7 Nomor 2. Hlm 43-44.

11 Soerjono Soekanto dan Sri Mamuji. 2010. Penelitian Hukum Normatif Suatu Tinjauan Singkat. RajaGrafindo Persada. Jakarta. Hlm. 13-14
} 
case is completed. Consequently, the parties will be hostages, either time, energy, or cost. Of course, this is contrary to the principle of judicial law is done simply, quickly and lightly, as is the case in the Constitutional Court. ${ }^{12}$

As a legislative decision (negative legislator), the nature of the final Constitutional Court ruling binds on all parties, whether citizens or state institutions in Indonesia. ${ }^{13}$ The Parties shall accept whatever the Constitutional Court ruling means. For the disadvantaged, technically jurisdiction can only accept these empirical facts in accordance with the provisions of the law for the settlement of the petition for judicial review of the law through the Constitutional Court.

Thus, despite the fact that the Constitutional Court ruling is final and binding, the empirical facts show that not all final and binding decisions may affect parliament and other state institutions (non-judicial actors). That is why the existence of regulations governing the authority and legal consequences of the final decision of the Constitutional Court, does not necessarily have real implications for the application of its verdicts, which in Indonesia may be perceived as non-binding. According to Syahrizal, this problem is caused by two things. Firstly, the Constitutional Court does not have an executor unit assigned to guarantee the application of the final decision (special enforcement agencies). Second, the final verdict relies heavily on the willingness of public authorities outside the Constitutional Court to follow up on the final decision. ${ }^{14}$

Final Strength and Binding Decision of the Constitutional Court Number 002/PUU-I/2003 in the Tests of Law Number 22 Year 2001 regarding Oil and Gas can be seen in Decision of the Constitutional Court stipulating that Article 12 paragraph (3), Article 22 paragraph (1) and Article 28 paragraph (2) and (3) are inconsistent with the Constitution of the Republic of Indonesia and have no binding legal force.

Subsequently to the Decision of the Constitutional Court Number 36/PUU-X/2012 in the Decision of the Constitutional Court stating that Article 1 Sub-Article 23, Article 4 Paragraph (3), Article 41 Paragraph (2), Article 44, Article 45, Article 48 Paragraph 1), Article 59 Sub-Article a, Article 61 and Article 63 of Law Number 22 Year 2001 regarding Oil and Gas are contradictory to the Constitution of the Republic of Indonesia and have no binding legal force. All matters relating to the Implementing Body in the Elucidation of Law Number 22 Year 2001 regarding Oil and Gas are contradictory to the Constitution of the Republic of Indonesia and have no binding legal force.

\section{The Executorial Power Decisions of the Constitutional Court:-}

The decision of the Constitutional Court which has a permanent legal force generally can be executed so that it can be called as having executional power. The verdict which has the executorial power is a verdict which expressly

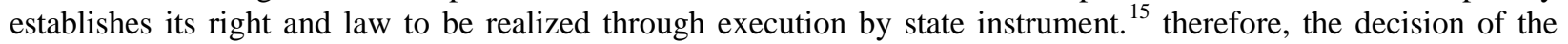
Constitutional Court is not sufficient only to bind, but also must be enforceable. According to the provision of Article 57 paragraph (3) of Law Number 24 of 2003 as amended by Law Number 8 Year 2011 regarding the Constitutional Court, the Executorial's power The Constitutional Court's decision is deemed to have materialized in the form of announcements contained in the state news in the most 30 days since the verdict was pronounced in a plenary session open to the public. Then, since publishing in the state news, and then the Constitutional Court decision must be implemented.

In the perspective of implementation, the final and binding decision on reality is not the only conclusive solution to the legal dispute argued by the applicant. In other words, the final decision also serves as a guide for determining the future legal development directions. This factor proves that the actual implementation of the final decision requires synergic cooperation between institutions and state apparatus. as long as the cross-institutional cooperation and the state apparatus has not been reached, we do not expect much from the application of the final decision of the Constitutional Court, and undoubtedly the verdict is only a symbolic power that adorns the State News.

\footnotetext{
${ }^{12}$ Ahsan Yunus. 2011. Analisis Yuridis Sifat Final dan Mengikat (Binding) Putusan Mahkamah Konstitusi. Jurnal Konstitusi Volume 3 Nomor 2, November 2011. Hlm 101.

${ }^{13}$ Budi. Suhariyanto. 2016. Masalah Eksekutabilitas Putusan Mahkamah Konstitusi oleh Mahkamah Agung. Jurnal Konstitusi. Volume 13 Nomor 1. HIm. 178

${ }^{14}$ Ahmad Syahrizal, Op.cit.HIm.118

${ }^{15}$ M. Nasir. 2003. Hukum Acara Perdata. Djambatan. Jakarta. HIm. 194.
} 
Based on Decision of Constitutional Court Number 002/PUU-I/2003, Executorial Strength of Court Decision is on the verdict which declares Ordered for this Decision to be published in State Gazette no later than 30 working days since this decision is declared. Subsequently to the Constitutional Court Decision Number 36/PUU-X/2012 is in the Decision Letter stating that the functions and duties of the Oil and Gas Executing Agency shall be implemented by the Government, in this case the relevant Ministries, until the passing new Law which regulates it.

\section{The Law Implications of Presidential Regulation as Follow Up From Decision of Constitutional Court In Judicial Review Number 22 Year 2001 About Oil and Gas.:-}

In this discussion, the author discusses two Presidential Regulations relating to the Law Implications of the Presidential Regulation as a follow-up of the Constitutional Court decision in the judicial review of Law Number 22 Year 2001 on Oil and Gas. First, the Legal Implication of Presidential Regulation Number 55/2005 on Retail Price of Domestic Fuel Oil as a follow up of the Decision of the Constitutional Court Number 002/PUU-I/2003. Secondly, Law Implications Presidential Regulation Number 09 of 2013 on the Management of Upstream Oil and Gas Business Activities as a follow up of the Decision of the Constitutional Court Number 36/PUU-X/2012.

First, The Law Implications Presidential Regulation Number 55 of 2005 about Retail Prices of Domestic Fuel Oil as a follow up of the Decision of the Constitutional Court Number 002/PUU-I/2003. Presidential Regulation Number 55 of 2005 which was born after the issuance of Law number 22 of 2001 on Petroleum and Gas in the judicial review by the Constitutional Court and has been published in State Gazette Number 1 Year 2005 dated January 4, 2005. In the decision of the Constitutional Court Number 002/PUU-I/2003 there are aspects that become considerations both juridically, sociologically and philosophically. In this section will be presented about the aspect of the conflict between Presidential Regulation Number 55 of 2005 and Law Number 22 of 2001 on Oil and Gas post judicial review by the Constitutional Court. Some basic points are related to the aspect of conflict in a juridical, sociological and philosophical perspective.

First, judicially, the fact that Presidential Regulation Number 55 of 2005 has no strong juridical basis because one of its considerations refers to legislation which has been declared to have no binding legal force through the mechanism of judicial review by the authorized institution. The result of the verdict from the test stated in Law Number 22 Year 2001 on oil and gas some articles have been deleted because of contradictory to the Constitution of the Republic of Indonesia and has no binding legal force.

Secondly, in addition to the issue of consideration, Presidential Regulation Number 55 Year 2005 article 9 paragraph (1) which relates to articles 1 point (4) and (5) clearly based on Article 28 paragraph (2) and (3) of Law number 22 of 2001 on Oil and Gas which has been declared to have no binding legal force in the judicial review of the Constitutional Court. The abolition of the provisions in Article 28 paragraph (2) and (3) of Law number 22 of 2001 on Oil and Gas as opposed to Article 33 Paragraph (4) of the Constitution of the Republic of Indonesia.

Presidential Regulation Number 55 of 2005 on Retail Prices of Domestic Fuel Oil, Article 9 paragraph (1) that says "Retail Price of Fuel Petroleum as referred to in Article 2, shall be adjusted to the economic price which may be an increase or decrease in price ". The Presidential Regulation also explains what is meant by the economic price as set forth in article 1 number to (5): "Economic Price is the price calculated per month based on the average MOPS in the previous one month period plus 15\% (fifteen per one hundred). Understanding MOPS in article 1 to number (4) is "Mid Oil Platt's Singapore (MOPS) is the price of buying and selling transactions at the oil exchange in Singapore."

The substance of Article 28 paragraph (2) and (3) of Law Number 22 Year 2001 states "paragraph (2) the price of fuel oil and gas price submitted to the mechanism of fair and reasonable business competition". Paragraph (3) The implementation of price policy as referred to in paragraph (2) shall not reduce the social responsibility of the Government towards certain segments of society. "

While in Article 33 Paragraph (4) of the Constitution of the Republic of Indonesia affirms that the national economy must be run on the principle of economic democracy. "The national economy is organized on the basis of economic democracy with the principles of togetherness, fair efficiency, sustainability, environmental insight, independence and by maintaining a balance of progress and national economic unity". 
The impact is very clear, the formulation of articles or provisions on legal norms in the Presidential Regulation that is contradictory to the higher regulations. The philosophical foundation that should be fully accommodated in Presidential Regulation Number 55 of 2005 on Retail Price of Domestic Fuel Oil, in essence, can't be implemented properly. This is evident from the existence of some mistakes and imperfections to the material content and technical preparation that not in line with the guidelines and provisions as regulated in Law Number 12 Year 2011 on the formation of legislation.

As in the hierarchy theory of legislation where there is a theory called Stufenbau theory. ${ }^{16}$ According to Hans Kelsen the legal norms are tiered and layered in the hierarchy of order. A lower norm applies, sourced and based on other higher norms. the higher norms are valid, sourced and based on other higher norms. ${ }^{17}$ Thus the norm applies, is sourced and applies to other higher norms to a norm that can not be traced again because of the hypothetical and fictitious nature of the so-called Basic Norms (Grundnorm) and determined by the society preceding (presupposed).If related to the theory, Presidential Regulation Number 55 of 2005 on Retail Price of Domestic Fuel Oil is hierarchically under Law Number 22 Year 2001 regarding Oil and Gas hierakis and based on the principles of legislation, the Presidential Regulation is contradictory to one of the principles stipulating that the laws and regulations below shall not be contrary to the higher laws and regulations (lex superiore derogat lex inferiore). ${ }^{18}$

Second, Law Implications Presidential Regulation Number 09 of 2013 on the Management of Upstream Oil and Gas Business Activities as a follow up of the Decision of the Constitutional Court Number 36/PUU-X/2012. The issuance of Presidential Regulation Number 95 of 2012 on the Transfer of Implementation of Duties and Functions of Upstream Oil and Gas Business Activities which was further followed up by Presidential Regulation Number 09 of 2013 on the Management of Upstream Oil and Gas Business Activities which established the Special Working Unit for Upstream Business Activities Oil and natural gas as a manager of upstream oil and gas activities shows that the government has inconsistencies in the management of oil and natural gas nationally. The replacement of the Oil and Gas Executing Agency which has been declared unconstitutional by the Constitutional Court to the Special Unit of oil and gas does not alter substantially the national oil and natural gas management system. The only difference we can find is the concept of the Supervisory Commission in a special unit of Oil and Gas that is less influential on the renewal of national oil and gas governance. The Special Unit of Oil and Gas conceptually doesn't appear to be different from the oil and gas implementing body where the formation of special oil and gas working units has the potential to increase the level and inefficiency of oil and gas management. The existence of the special Oil and Gas working unit clearly ignores the legal considerations of the Constitutional Court decision to be potential is called unconstitutional.

Position and Authority of the special Oil and Gas Special Unit as the substitute of the Oil and Gas Executing Agency. The existence of a special Oil and Gas Unit in the oil and gas world in Indonesia is new one. The Legal Status of The special oil and gas working unit based on Presidential Regulation Number 95 of 2012 concerning the Transfer of Implementation of Duties and Functions of Upstream Oil and Gas Business Activities and Presidential Regulation Number 9 of 2013 on the Implementation of Upstream Oil and Gas Business Management is to replacing the role of the Oil and Gas Executing Agency in terms of carrying out the functions of control and supervision of upstream business activities in the oil and gas.

Overall, the Constitutional Court overturned Article 1 Sub-Article 23, Article 4 Paragraph (3), Article 41 Paragraph (2), Article 44, Article 45, Article 48 Paragraph (1), Article 59 Sub-Article a, Article 61, Article 63 of Law Number 22 of 2001 on Oil and Gas. The Constitutional Court also canceled the phrase 'with the Implementing Body' in Article 11 paragraph (1), the phrase 'through the Implementing Body' in Article 20 paragraph (3), the phrase 'based on consideration of the Implementing Body and' in Article 21 paragraph (1) the phrase 'Implementing Agency and in Article 49 of Law Number 22 Year 2001 concerning Oil and Natural Gas. All articles by the Constitutional Court are considered opposing to Article 33 of the Constitution of the Republic of Indonesia.

\footnotetext{
${ }^{16}$ Budiman N.P.D Sinaga. 2004. Ilmu Pengetahuan Perundang-undangan. UII Press. Yogyakarta. Hlm. 18

17 Romi Librayanto, A. Pangerang Moenta, Achmad Ruslan, Marwati Riza. 2015. The Concretization of Legal Norms Based on the 3C Theory by MacCormick (A Review of the Indonesian Constitutional Court's Decision No: 011/PUU-III/2005 and 012/PUU- III/2005). International Journal of Advanced Research. Volume 3 Issue 11. HIm. 853

${ }^{18}$ M. Mahrus Ali. 2007. Meninjau Ulang Inkonstitusional Peraturan Presiden tentang Bahan Bakar Minyak. Jurnal Hukum Nomor 1 Volume 14. Hlm 24
} 
The functions owned by the oil and gas working unit together with the function of the Oil and Gas Executing Agency must show for the the treatment of national oil and gas governance will be maintained. While such a function has been recommended not to be used again. Based on the regulations issued by the government related to the national oil and gas management further post the dissolution of the Oil and Gas Executing Agency by the Constitutional Court, to the Special Unit for Oil and Gas. It is seen from the regulation which has been issued of no difference between Oil and Gas Executing Agency, Temporary Working Unit of Oil and Gas Executor and Special Unit of Oil and Gas, the name of institution is different, however task, function, funding organization, asset, and personel are still the same. This means the government has not seriously improved the governance of oil and gas. Can be seen in the table below:

Table 1:-Development of National Oil and Gas Management After the Constitutional Court Decision Number 36/PUU-X/2012

\begin{tabular}{|c|c|c|c|}
\hline Number & $\begin{array}{l}\text { Oil and Gas Executing } \\
\text { Agency in Law Number } \\
22 \text { Year } 2001\end{array}$ & $\begin{array}{l}\text { Temporary Working Unit } \\
\text { of Oil and Gas Executor } \\
\text { In Presidential Regulation } \\
\text { Number } 95 \text { Year } 2012\end{array}$ & $\begin{array}{l}\text { special oil and gas working } \\
\text { unit in Presidential } \\
\text { Regulation Number } 9 \text { of } 2013\end{array}$ \\
\hline 1. & $\begin{array}{l}\text { The Head of the Oil and } \\
\text { Gas Executing Agency } \\
\text { shall be appointed and } \\
\text { dismissed by the } \\
\text { President after } \\
\text { consultingwith the } \\
\text { Legislative Assembly } \\
\text { and in the performance } \\
\text { of its duties accountable } \\
\text { to the President. }\end{array}$ & $\begin{array}{l}\text { Temporary working units } \\
\text { of upstream oil and gas } \\
\text { business activities are } \\
\text { under and responsible to } \\
\text { the minister of energy } \\
\text { and mineral resources. }\end{array}$ & $\begin{array}{l}\text { The head of the Special Oil } \\
\text { and Gas Working Unit is } \\
\text { appointed and dismissed by } \\
\text { the president upon the } \\
\text { proposal of the minister, } \\
\text { after receiving } \\
\text { consideration from the } \\
\text { supervisory commission. } \\
\text { The Head of Oil and Gas } \\
\text { Special Unit is directly } \\
\text { responsible to the president. }\end{array}$ \\
\hline 2. & $\begin{array}{l}\text { The oil and gas execution } \\
\text { body consists of } \\
\text { elements of leadership, } \\
\text { experts, technical } \\
\text { personnel, and } \\
\text { administrative personnel. }\end{array}$ & $\begin{array}{l}\text { The organizational } \\
\text { structure of the } \\
\text { temporary Working Unit } \\
\text { is the same as the Oil and } \\
\text { Gas Executing Body in } \\
\text { Law Number } 22 \text { of } 2001 \\
\text { on oil and gas. }\end{array}$ & $\begin{array}{l}\text { Organizational Structure of } \\
\text { Oil and Gas Special } \\
\text { Working Units as } \\
\text { comprised of: } \\
\text { head, deputy head, } \\
\text { secretary, internal } \\
\text { supervisor, and } \\
\text { deputy. }\end{array}$ \\
\hline 3. & $\begin{array}{l}\text { Oil and Gas Executing } \\
\text { Agency exercises } \\
\text { supervision over upstream } \\
\text { business activities in order } \\
\text { to obtain natural resources } \\
\text { of state-owned oil and gas } \\
\text { to provide maximum } \\
\text { benefit and acceptance for } \\
\text { the state to the greatest } \\
\text { possible prosperity of the } \\
\text { people. The task of the Oil } \\
\text { and Gas Executing } \\
\text { Agency in Article } 44 \text { of } \\
\text { Law Number } 22 \text { Year } \\
\text { 2001 of Oil and Gas is the } \\
\text { same as the Special Unit } \\
\text { for Oil and Gas. }\end{array}$ & $\begin{array}{l}\text { Tasks, functions and } \\
\text { organization The special } \\
\text { unit while the oil and gas } \\
\text { executive is the same as } \\
\text { the Oil and Gas } \\
\text { Executing Body in Law } \\
\text { Number } 22 \text { of } 2001 \text { on } \\
\text { oil and gas, whose duties } \\
\text { and functions are only } \\
\text { transitional ones. }\end{array}$ & $\begin{array}{l}\text { The task of the Special Unit } \\
\text { of Oil and Gas to carry out } \\
\text { the management of } \\
\text { upstream oil and gas } \\
\text { business activities based on } \\
\text { the Cooperation Contract in } \\
\text { order to obtain the State Oil } \\
\text { and Gas Minerals } \\
\text { Resources can provide } \\
\text { maximum benefits and } \\
\text { acceptance for } \\
\text { State for the greatest } \\
\text { prosperity of the people. } \\
\text { The function of the Special } \\
\text { Oil and Gas Working Unit } \\
\text { is the same as the Oil and } \\
\text { Gas Executing Body in } \\
\text { article } 3 \text { of Ministerial } \\
\text { Regulation Number } 09 \text { Year } \\
\text { 2012 which was revoked } \\
\text { and replaced by Ministerial }\end{array}$ \\
\hline
\end{tabular}




\begin{tabular}{|l|l|l|l|}
\hline & & & $\begin{array}{l}\text { Regulation Number 17 of } \\
2017 \text { is the same task and } \\
\text { function of special units of } \\
\text { oil and gas work. }\end{array}$ \\
\hline
\end{tabular}

Source: Primary data, 2018

This shows that the error of oil and gas regulation implemented by the Oil and Gas Executing Agency is repeated by the Oil and Gas Special Unit. so the development of the arrangement can be said to be invalid. Thus, the Oil and Gas Special Working Unit is a failure again in oil and gas management. in the end the formation of special working unit of oil and gas is also inseparable from unscrupulous executor of business and unscrupulous government which becoming point of problem of oil and gas regulation.

The formation of a special oil and gas working unit which becomes an extension of the government as a representation of the state's domination of national natural wealth doesn't show any significant change in the national oil and gas management. The existence of the current Special Oil and Gas Working Unit when analyzed in the constitutional aspect, the position of the Oil and Gas Special Unit will be unconstitutional. This writer can describestarted from the reuse of article content that has been decided by the Constitutional Court is contradictory to the Constitution of the Republic of Indonesia on the rules for the formation of the Special Unit for Oil and Gas. Viewed from the provisions such as related to operational cost budgeting in Article 18 of Presidential Regulation Number 9 of 2013 and the main tasks and functions contained in Article 3 of Regulation of the Minister of Energy and Mineral Resources Number 9 of 2013 which has been revoked and replaced by Regulation of the Minister of Energy and Mineral Resources, Number 17 of 2017 on the Organization and Working Procedures of the Special Unit for Upstream Oil and Gas Business Activities is the same as in Article 44 and 48 paragraph (1) which has been declared on the contrary to the Constitution. While on the other hand, if one rule is declared that the content of paragraphs, chapters and/or paragraphs of the tested law have no longer binding legal force, then the content of paragraphs, articles and/or parts of the law being tested shall no longer be enacted. This clearly shows that the government has been counter productive to the decisions issued by the Constitutional Court.

\section{Conclusions:-}

Final Strength and Binding Decisions the Constitutional Court has obtained a permanent legal force since the verdict was pronounced and no legal remedy can be taken, and not only applied to parties but applied to all citizens. The Executorial Power the Constitutional Court's decision is the power to evaluate what is imposed in the decision by the means of the state. Law Implications the Presidential Regulation on the Constitutional Court Decision lies with the decision of the Constitutional Court declaring that Article that is tested in Law Number 22 Year 2001 regarding Oil and Natural Gas is contradictory to the Constitution of the Republic of Indonesia and has no binding legal force, should be followed up with actions. However, the fact that the Constitutional Court Decision is followed up by Presidential Regulation.

\section{References:-}

\section{Book:-}

1. Bambang Sutijoyo dan Sri Hastuti Puspitasari. 2005. Aspek-Aspek Perkembangan Kekuasaan Kehakiman Indonesia. UII Press. Yogyakarta.

2. Budiman N.P.D Sinaga. 2004. Ilmu Pengetahuan Perundang-undangan. UII Press. Yogyakarta.

3. Jimly Asshiddiqie. 2010. Konstitusi dan Konstitusionalisme Indonesia. Sinar Grafika. Jakarta.

4. M. Nasir. 2003. Hukum Acara Perdata. Djambatan. Jakarta.

5. Marwan Effendy. 2005. Kejaksaan RI: Posisi dan Fungsinya Dari Perspektif Hukum. Gramedia Pustaka Utama. Jakarta.

6. Maria Farida Indrati S. 2007. Ilmu Perundang-Undangan 1. Penerbit Kanisius. Jakarta.

7. Moh. Mahfud MD. 2007. Perdebatan Hukum Tata negara Pasca Amandemen Konstitusi. LP3ES. Jakarta.

8. Soerjono Soekanto dan Sri Mamuji. 2010. Penelitian Hukum Normatif Suatu Tinjauan Singkat. RajaGrafindo Persada. Jakarta. 


\section{Journal:-}

1. Ahmad Syahrizal. 2007. "Problem Implementasi Putusan Mahkamah Konstitusi”. Jurnal Konstitusi, Volume 1, Nomor 4, Maret 2007.

2. Ahsan Yunus. 2011. Analisis Yuridis Sifat Final dan Mengikat (Binding) Putusan Mahkamah Konstitusi. Jurnal Konstitusi Volume 3 Nomor 2, November 2011.

3. Budi. Suhariyanto. 2016. Masalah Eksekutabilitas Putusan Mahkamah Konstitusi oleh Mahkamah Agung. Jurnal Konstitusi. Volume 13 Nomor 1.

4. Ivan Fauzani Raharja. 2016. Penerapan Sanksi Administrasi Terhadap Perusahaan Yang Melanggar Ketentuan Perizinan Minyak dan Gas Bumi. Jurnal Ilmu Hukum, Volume 7 Nomor 2.

5. M. Mahrus Ali. 2007. Meninjau Ulang Inkonstitusional Peraturan Presiden tentang Bahan Bakar Minyak. Jurnal Hukum Nomor 1 Volume 14.

6. Romi Librayanto, A. Pangerang Moenta, Achmad Ruslan, Marwati Riza. 2015. The Concretization of Legal Norms Based on the 3C Theory by MacCormick (A Review of the Indonesian Constitutional Court's Decision No: 011/PUU-III/2005 and 012/PUU- III/2005). International Journal of Advanced Research. Volume 3 Issue 11. 